\section{Correlations between fractal dimension of mandibular condylar bone and Degenerative Joint Disease - A CBCT based analysis}

\section{Mandibular kondilar kemiğe ait fraktal boyut değerleri ve dejeneratif eklem hastalığı bulguları arasındaki korelasyon: Dental tomografi temelli bir analiz}

\author{
Assist. Prof. İsmail Gümüssoy \\ Sakarya University, Faculty of Dentistry, \\ Department of Dentomaxillofacial Radiology, Sakarya \\ Orcid ID: 0000-0002-2725-3273
}

Assist. Prof. Suayip B. Duman

İnönüUniversity, Faculty of Dentistry,

Department of Dentomaxillofacial Radiology, Malatya

Orcid ID: 0000-0003-2552-0187

Assist. Prof. İbrahim S. Bayrakdar

Osmangazi University, Faculty of Dentistry,

Department of Dentomaxillofacial Radiology, Eskişehir

Orcid ID: 0000-0001-5036-986

Assist. Prof. Yasin Yasa

Ordu University, Faculty of Dentistry,

Department of Dentomaxillofacial Radiology, Ordu

Orcid ID: 0000-0002-4388-2125

Prof. Binali Cakur

Ataturk University, Faculty of Dentistry,

Department of Dentomaxillofacial Radiology, Erzurum

Orcid ID: 0000-0002-8525-1444

Received: 8 November 2018

Accepted: 2 May 2019

doi: 10.5505/yeditepe.2019.07769

\section{Correspondig author:}

Dr. Ismail Gümüsssoy

Department of Dentomaxillofacial Radiology,

Faculty of Dentistry, Sakarya University, Sakarya, Turkey

Phone: +90 2642954201

E-mail: ismgum@gmail.com

\section{SUMMARY}

Aim: The aim of this study was to determine whether correlations existed between the fractal dimension (FD) value of the mandibular condyle and radiographic findings of degenerative joint disease (DJD) using cone beam CT (CBCT).

Materials and Method: 100 TMJ CBCT images were retrospectively analyzed. CBCT images of patients were assessed with regard to erosive degenerative bone change (DBC) in the mandibular condyle. We divided each condyle into 3 groups and scored $(0,1,2)$ according to diagnosis of DJD: with 0 indicating normal condyles or non-demonstrable change, 1 indicating mild erosive DBC and 2 indicating severe erosive DBC. Fractal analysis (FA) was applicated to CBCT image of mandibular condyle. FD values were compared with the radiographic diagnosis scores.

Results: ANOVA test showed that there was statistically significant difference between the FD values of patient with erosive $\mathrm{DBC}$ and patient having no erosive change. The average FD value of patient group 0 was 1.079 , the average FD value of patient group 1 was 1.052, the average FD value of patient group 2 was 1.036. Lower FD values and more severe degenerative changes were seen in patient group 2.

Conclusion: In our study, we found that as the grade of bone degeneration increased, FD values decreased. These findings suggest a promising result in related topic. However, this paper is a preliminary study of FA and DBC. Further studies should be performed to ensure FA is clinically feasible.

Keywords: Mandibular condyle, cone beam CT, fractal analysis

ÖZET

Amaç: Bu çalışmanın amacı dental volumetrik tomografi (DVT) kullanılarak elde edilen dejeneratif eklem hastalığında mandibular kondile ait radyografik bulgular ile fractal boyut (FB) değerleri arasında korelasyon olup olmadığını araştırmaktır.

Gereç ve Yöntem: 100 DVT eklem görüntüsü retrospektif olarak incelendi. Hastaların DVT görüntüleri mandibular kondilde eroziv dejeneratif kemik değişimi (DKD) açısından incelendi ve her bir kondil buna göre üç gruba ayrılarak skorlandı $(0,1,2)$ : 0 normal kondili, 1 kondilde hafif derece eroziv DKD, 2 kondilde ileri derece eroziv DKD göstermektedir. Fraktal analiz (FA), mandibular kondil DVT görüntüleri üzerine uygulandı ve radyografik diagnoz skorları ile karşılaştırıldı.

Bulgular: Anova test değerleri, kondilde eroziv DKD olan hastaların FB değerleri ile olmayanlar arasında istatistiksel olarak anlamlı derecede farklılık olduğunu gösterdi. Hasta grubu 0 'da ortalama FB değeri 1.079, grup 2'de 1.052 ve grup $3^{\prime}$ de 1.036 idi. Daha yüksek dejeneratif 
değişimlerin görüldüğü hasta grubu 2'de daha düşük FB değerleri görüldü.

Sonuç: Çalışmamızda, kemik dejenerasyon derecesi arttıkça FB değerlerinin de azaldığını gözlemledik. Bu bulgular konuyla ilgili umut verici bir sonuç ortaya koymakla beraber, bu araştırma FA ve DKD ile ilgili bir ön çalışmadır ve $F A^{\prime}$ in klinik olarak uygulanabilir olması için daha ileri çalışmalar yapılmalıdır.

Anahtar kelimeler: Mandibular kondil, dental volumetrik tomografi, fraktal analiz

\section{INTRODUCTION}

Fractal is a term that expresses complex shapes which cannot be defined by Euclidean geometry. Shapes that have fractal features presents self-similarity and are very different from simple shapes like as circle, sphere and square in Euclidean geometry. Size of dot is zero, line's is one, plane's is two and volume's is three in Euclidean geometry. Whereas fractals do not have a whole number dimension - they have a fractional dimension..$^{1-3}$ The texture of images consist of many small components that present fractal features. Many methods have been developed for analysis of this texture by researchers. Fractal applications is a method of texture analysis to define complex shapes and structures. Over the past years, use of fractal analysis (FA) has expanded in many scientific disciplines especially biology and medicine. ${ }^{4}$

Temporomandibular joint (TMJ) has a different value than other joints in human body in terms of its region and functions. Etiology, assessment and treatment of Temporomandibular joint disorders (TMD) is unclear and complicated due to the fact that numerous complex components which composed it. TMD affects the TMJ, muscles and/or related structures. ${ }^{5}$ However, hard tissue degenerative joint disease (DJD) affects the bony structures of TMJ, such as erosion, flattening, osteophytes, pseudocysts and sclerosis. Erosive degenerative bone changes (DBC), a common finding in DJD, are frequently observed at the mandibular condyle head. ${ }^{6}$ Pain, clicking or crepitus and restriction of mouth-opening are the most common clinical signs of erosive DBC in DJD. Nevertheless, erosive DBC might not manifested any clinical finding and might be accidentally found on radiographs during the initial stage. ${ }^{6,7}$ DJD are often caused by increased loading of the joint. Microstructure of trabecular bone has a very important role in mechanical loading on TMJ.

Cancellous bone presents fractal properties such as self-similarity, complexity and characteristic length due to its natural architecture. Cancellous bone is metabolically more active and it has a higher bone-cycle rate than compact bone. Thus, it is better indicator of metabolic activity and it presents more valuable diagnostic information than compact bone. Therefore, FA may be used to define the complex architecture of cancellous bone., ${ }^{2,8}$ In many studies in the literature, it has been reported FA of cancellous bone is a practical, low-cost and promising tool for the evaluation of bone tissue..$^{8-12}$ Researchers have used FA to evaluation of gingivitis and periodontitis or osteoporosis. They noted that FA has been capable to discriminate the patient with gingivitis from patient with periodontitis or discriminate the patients with osteoporosis from patient without osteoporosis using radiographs. ${ }^{2,13-16}$ Structural features of the condylar trabecular bone is one of the important factors in determining of DJD. ${ }^{5,17}$ A good understanding about these structural bony changes is critical in order to early diagnose and prevention or treatment of disease.

In this paper, we hypothesized that condylar trabecular bone microstructure would be significantly correlated with DJD development. With the aim of this, we applicated FA to condylar trabecular bone and we assessed the correlations between FA results and radiographic findings of DJD.

\section{MATERIALS AND METHODS}

In this retrospective study, TMJ CBCT images of patients who were referred to our clinic because of TMJ complaints were used. 100 TMJ CBCT images from 61 patients radiographically analyzed. In determining an association between FD of trabecular bone and radiographic diagnosis of DJD, we sorted each condyle into 3 groups and scored $(0,1,2)$ based on the criteria published by Muir and Goss. ${ }^{18}$ Group 0 indicating normal condyles or non-demonstrable change, group 1 indicating mild DBC and group 2 indicating severe DBC. Radiographic bony changes in DJD include erosion, flattening, sclerosis, and osteophytes. In this paper, only erosive type of DJD samples were included to the study. Some of TMJ CBCT images were excluded because of inadequate data such as patient movements and metal artifacts. Also, some of patients did not included due to medical conditions such as hyperparathyroidism, renal insufficient, systemic steroid use, and osteoporosis that can affect bone metabolism. The age range was $21-50$ years, with a mean age of 26 years. 13 patients were male and 48 patients were female. All procedures performed in our study were in accordance with the Helsinki Declaration of 1964 and later versions.

All radiographic examinations were performed using a CBCT (NewTom 3G, Quantitative Radiology, Verona, Italy). The exposure parameters were set with a maximum output of $110 \mathrm{kV}$ and $15 \mathrm{mAs}$, 9-inch field of view, $160 \rrbracket$ voxel size, active exposure time of 5.4 seconds. The QR-NNT version 2.21 (Quantitative Radiology) software was used for evaluation. The sagittal slice of condyle head was performed perpendicular to the long axis of the condyle head and the coronal slices were performed pa- 
rallel to the long axis of the condyle head on the selected axial image. The thickness and distance between the slices were set to1-mm.

The existence and severity of erosive DBC in the mandibular condyle were radiographically assessed by the dentomaxillofacial radiologist. We only considered radiographic evaluation of DJD to compare with FD value. Each patient was grouped and scored between 0 and 2 for erosive DBC according to method of Muir and Goss. ${ }^{18}$ Representative images of the patient categories are presented in Figure 1.

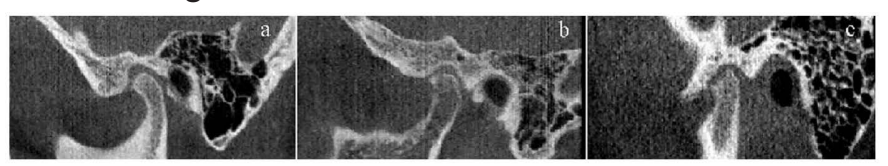

Figure 1. Erosive degenerative bone changes (DBC) in the mandibular condyle. The changes consisted of: normal condyle or non-demonstrable change (a); mild
erosive DBC (b); severe erosive DBC (c)

To evaluate the intra-observer reliability, the reconstructions were evaluated twice by an expert dentomaxillofacial radiologist with 5 years of experience and bone degeneration had to be seen in at least three consecutive slices to avoid misinterpretation. A minimum interval of 10 days between evaluations of the same patient was established.

Box counting method as designed by White and Rudolph $^{13}$ was used to perform FA on the mandibular condyle (Figure 4). One of the coronal view on which the condyle head were appeared the widest medio-lateral extent was selected to make FD analysis for each patients. The size of regions of interest (ROIs) was set to $15 \times 15$ pixels on this coronal slice (Figure 2-3).

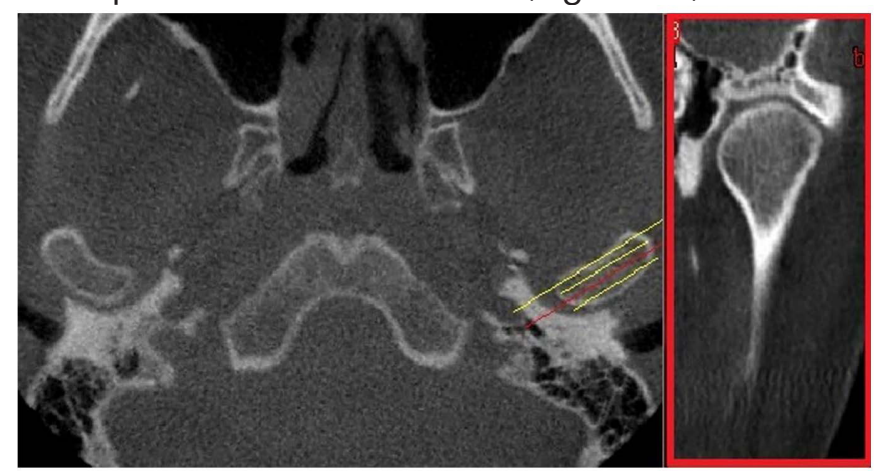

Figure 2. Preparation of coronal slices to selection of ROI

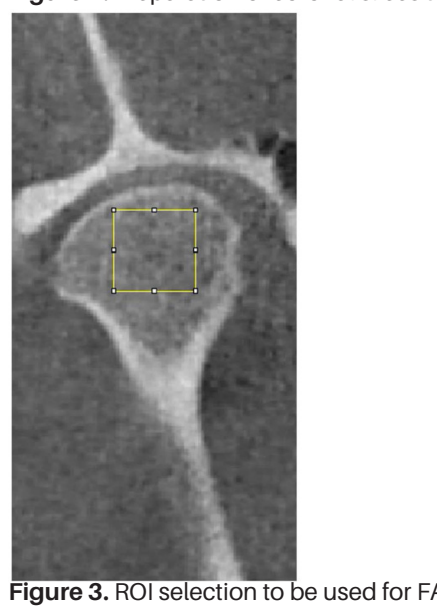

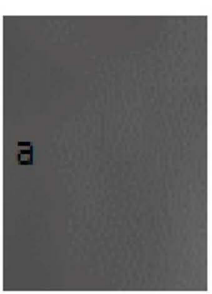
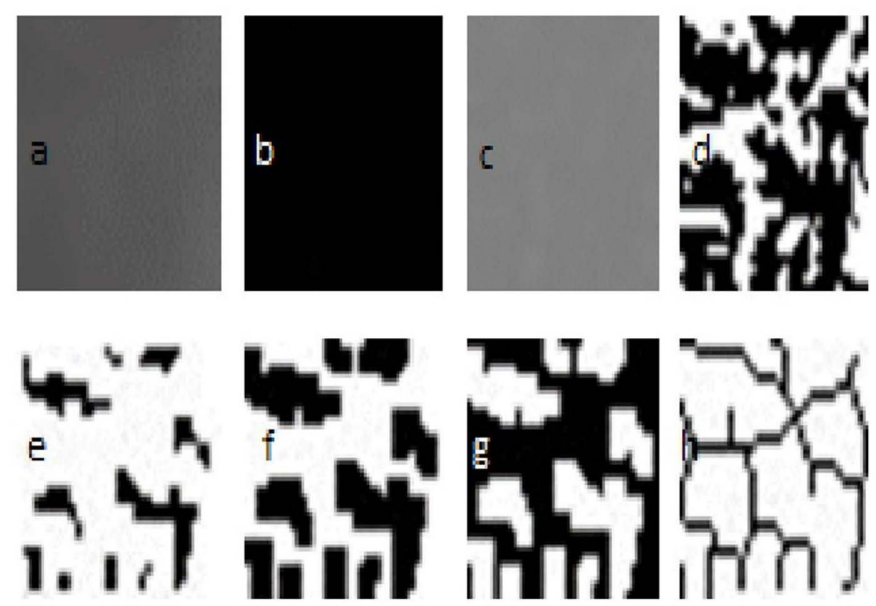

Figure 4. FD analysis transactions. a. Blurred image of the cropped and duplicated $\mathrm{RO}, \mathrm{b}$. The blurred image was then subtracted from the original image, c. Ad ding 128 to the result, d. Application of 128 threshold value, e. Erosion process, f. Dilatation process, g. Reversing, h. Skeletonizing

Boundary of compact bone was not included to ROIs, only cancellous bone selected. FA transactions were performed by the same person and ImageJ 1.46r image analysis program (National Institutes of Health, Bethesda, MD;http://rsb.info.nih. gov/nih-image). This version has been obtained free of charge from the website "http: rsb. info.nih.gov".

Statistical Analysis

Results were analyzed using SPSS software (IBM, SPSS VERSION 22.0, Chicago, IL, USA). ANOVA statistic test was performed to assess FD values and bone degeneration scores. Least Significant Difference (LSD) post hoc test was used in determining the source of difference between the groups. Results were reported as mean \pm standard error and a level of $p<0.05$ was accepted as statistically significant.

\section{RESULTS}

Study group consisted with 61 people and 100 TMJs. Group 0 consisted with 32 TMJs, group 1 consisted with 44 TMJs and group 2 consisted with 24 TMJs. FD values of the patients are presented in Table 1.

Table 1. Average FD values of patient groups

$\begin{array}{llll} & \text { Group 0 } & \text { Group 1 } & \text { Group 2 } \\ \text { average FD value } & 1,079 & 1,052 & 1,036 \\ \text { number of TMJ } & 32 & 44 & 24\end{array}$

Average FD value of patient group 2 were lower than the patient group 1 and average FD value of patient group 1 were lower than the patient group 0 . The average FD value of group 0 was 1.079, the average FD value of patient group 1 was 1.052, the average FD value of patient group 2 was 1.036. ANOVA test showed that there was statistically significant difference between the FD values of patient with erosive DBC and patient having no erosive change (Table 2). 
Table 2. AANOVA Statistics of fractal dimension (FD) values in relation to severity of degenerative changes

$\begin{array}{lcccccc} & \begin{array}{c}\text { Sum of } \\ \text { Squares }\end{array} & \text { df } & \text { Mean Square } & \text { F } & \text { Sig. } \\ \text { Between Groups } & , 028 & 2 & , 014 & 4,925 & , 009 \\ \text { Within Groups } & , 274 & 97 & , 003 & & \\ \text { Total } & , 302 & 99 & & & \end{array}$

LSD test showed that there was significant difference in FD values between the patient group 0 and 1, 2. There was not significant difference between the patient group 1 and 2 (Table 3 ).

Table 3. LSD post hoc test was used in determining the source of difference between the patient groups

\begin{tabular}{|c|c|c|c|c|}
\hline Comparison & Diff of Means & Std.Error & Sig. (P) & Diff >= LSD \\
\hline group 0 vs. group 1 & 0,0277 & 0,0123 & $0,027^{*}$ & Yes \\
\hline group 0 vs. group 2 & 0,0433 & 0,0143 & $0,003^{*}$ & Yes \\
\hline group 1 vs. group 2 & 0,0156 & 0,0134 & 0,250 & No \\
\hline
\end{tabular}

LSD: Least Significant Difference test, " $\mathrm{p}<0.05$ was accepted as statistically significant

\section{DISCUSSION}

In this paper, we studied whether there is association between fractal dimension of trabecular bone and radiographic diagnosis of DJD. With the aim of this, we evaluated the СВCT images of patients who were referred because of TMJ complaints. Only radiographic diagnosis of bone changes and FD values have been compared regardless of clinical findings.

In the field of dental radiology, qualitative and quantitative bone evaluation have an important role on assessment of bone healing after implant replacement, preoperative implant planning, endodontic and orthognatic surgery and showing changes of trabecular structure in patients with metabolic bone disorders and TMD. ${ }^{19}$ Recent studies reported that structural properties of the mandibular condyles of the TMJ are one of the most important factors in determining DJD. ${ }^{5,17}$ However, radiologists examine whether there are visible bone changes while evaluating CBCT images of TMD patients. Some of studies reported that even small trabecular changes can be determined with FA in early stage of disorders. ${ }^{2,20,21}$ FA is a method that can provide the objective, mathematical image analysis and microstructure of bone can be evaluated using FA. From engineering to medical, the use of FA is very wide and it was also used in plenty of research in dental fields. FA has been used for image analysis of trabecular bone structure of patients with osteoporosis, hyperparathyroidism and implant planning. ${ }^{13,22-28}$ In a radiography study on the relationship between periodontal disease and bone destruction, it was reported that the destructive effects of periodontal pathology on trabecular bone can be successfully evaluated with FA. Researchers have stated that even small trabecular destructive changes in the early stages of the disease can be determined by FA before the effects of periodontal pathology are clearly emerged. ${ }^{2}$
In our study, there was significant difference in FD values between the patient group 0 and groups 1,2. Our results are partially consistent with previous studies. Arsan et al. ${ }^{29}$ stated that

FD value decreased as the level of bone degeneration increased in TMD patients. Arsan et al. ${ }^{29}$ associate this obtained results with loss of complexity in the trabecular structure and leads to a smoother form transformation by the effect of degenerative bone changes. Updike and Nowzari ${ }^{2}$ also pointed out that the demineralization-resorption process which started with periodontal disease caused to a decrease on trabecular complexity and consequently lead to a decrease in FD value. Many studies in the literature have pointed out that a higher value of fractal in the trabecular bone structure would indicate a more complex architecture. ${ }^{15}$ With this in mind, there is no consensus on how destructive bone changes caused by diseases affect the complexity of the trabecular structure and how it affects outcomes of FA. Therefore, different FA results have been obtained in different studies. For instance, researchers such as Ruttimann et al. ${ }^{26}$ and Hua et al. ${ }^{19}$ have stated that FD values increase in pathologies that cause osteoporosis-like effect on trabecular bone. Some other researchers such as Demirbaş et al., ${ }^{30}$ Southard et al., ${ }^{11}$ Updike et al. ${ }^{2}$ and Ergün et al. ${ }^{23}$ have come to conclusion that FD value decreases, as is the conclusion in our study.

Kayipmaz et al. ${ }^{31}$ carried out a study using FA on CBCT images of 35 healthy TMJs and 35 TMJs with osteoarthritis. They stated that FA can be used as an auxiliary method to achieve early detection of TMD. Kayipmaz et al. ${ }^{31}$ classified the patient with TMD as a single group. Unlike their study, we grouped and scored the patients with TMD according to degree of degeneration. There are numerous studies on the classification and diagnostic definitions of TMD (Akerman et al., ${ }^{32}$ Muir and Goss, ${ }^{18}$ Flygare et al., ${ }^{33}$ and Ahmad and Schiffman ${ }^{34}$ ). We used the TMD grading system and diagnostic definitions developed by Muir and Goss. ${ }^{18}$ By the aid of this diagnostic definitions system, the severity of degenerative changes are demonstrable in numerical values and can be compared with FD values. According to Muir and Goss, radiographic findings of TMD include degeneration of the condylar head due to surface erosion, subcortical cysts, loose calcified bodies, generalized sclerosis, and osteophytes. Due to the fact that cystic and calcified bone structures are not suitable to assessment with FA, we included to the study only erosive type of DJD samples for the accurate assessment with FA.

The limitations of this study were firstly that it is not possible to histopathologically evaluate how changes in bone structure caused by TMD. Another limitation was that our CBCT system had big FOV size and big voxel size. 
СВСТ gives valuable information to evaluation of bony structure of TMJ and $\mathrm{CBCT}$ is a reliable diagnostic tool which are not involved many negative factors when the compared with panoramic radiographs for assessment of bone structure of TMJ.6,35,36 Panoramic radiographs leads to superimposition, distortion and magnification. ${ }^{37}$ CBCT provides a sectional images of TMJ that eliminates superposition of cortical bones. On the other hand, there are a lot of CBCT systems according to technical factors such as detector type, scan FOV selection and voxel size. All this factors influence the image quality and ability of CBCT systems to imaging anatomical structures. ${ }^{38} \mathrm{Ibra}-$ him et al. ${ }^{39}$ reported that small voxel size in a small FOV size is recommended to better visualize the anatomical structures. There was not significant difference between the FD values and bone degeneration degree of patient groups 1 and 2. We associated this result with inadequate technical factors related to image resolution such as big voxel size and FOV. Micro-CT surely superior to CBCT, but it is not possible to use in human research. Future studies may be performed using micro-CT on animal models. Consequently, we calculated the FD value of mandibular condyle in patients with TMD and compared with radiographic diagnosis of patients. Lower FD values were found in groups with higher bone degeneration grade. This study showed that FA is a promising tool to evaluate the alteration of trabecular structure in patients with TMD. However, further broader studies should be conducted with histopathology and micro-CT findings to demonstrate the clinical reliability of FA using $\mathrm{CBCT}$ images.

\section{Data Availability}

The data used to support the findings of this study are available from the corresponding author upon request.

\section{Acknowledgements}

None

\section{Compliance with Ethical Standards}

All procedures followed were in accordance with the Helsinki Declaration of 1964 and later versions.

\section{Informed consent}

For this type of study, formal consent is not required.

\section{Conflict of Interest}

Authors declare that they have no conflict of interest.

\section{Funding}

This work was not supported by any foundation.

\section{REFERENCES}

1. Geraets WG, Van der Stelt PF. Fractal properties of bone. Dentomaxillofac Radiol 2000; 29: 144-53.

2. Updike SX, Nowzari H. Fractal analysis of dental radiographs to detect periodontitis-induced trabecular changes. J Periodontal Res 2008; 43: 658-64.

3. Mandelbrot B. Fractal Geometry of Nature. Edition. New York, ABD, W. H. Freeman and Company; 1983.

4. Smith TG, Jr., Lange GD, Marks WB. Fractal methods and results in cellular morphology--dimensions, lacunarity and multifractals. J Neurosci Methods 1996; 69: $123-$ 136.

5. Tanaka E, Detamore MS, Mercuri LG. Degenerative disorders of the temporomandibular joint: etiology, diagnosis, and treatment. J Dent Res 2008; 87: 296-307.

6. dos Anjos Pontual ML, Freire JS, Barbosa JM, Frazao MA, dos Anjos Pontual A. Evaluation of bone changes in the temporomandibular joint using cone beam CT. Dentomaxillofac Radiol 2012; 41: 24-29.

7. Yi W-J, Heo M-S, Lee S-S, Choi S-C, Huh K-H, et al. Direct measurement of trabecular bone anisotropy using directional fractal dimension and principal axes of inertia. Oral Surg Oral Med Oral Pathol Oral Radiol Endod 104: 110-116.

8. Fazzalari .L, Parkinson IH. Fractal properties of cancellous bone of the iliac crest in vertebral crush fracture. Bone 1998; 23: 53-57.

9. Law AN, Bollen AM, Chen SK. Detecting osteoporosis using dental radiographs: a comparison of four methods. J Am Dent Assoc 1996, 127: 1734-1742.

10. Southard TE, Southard KA, Jakobsen JR, Hillis SL, Najim CA. Fractal dimension in radiographic analysis of alveolar process bone. Oral Surg Oral Med Oral Pathol Oral Radiol Endod 1996; 82: 569-576.

11. Southard TE, Southard KA, Krizan KE, Hillis SL, Haller JW, et al. Mandibular bone density and fractal dimension in rabbits with induced osteoporosis. Oral Surg Oral Med Oral Pathol Oral Radiol Endod 2000; 89: 244-249.

12. Southard TE, Southard KA, Lee A. Alveolar process fractal dimension and postcranial bone density. Oral Surg Oral Med Oral Pathol Oral Radiol Endod 2001; 91: 4864891.

13. White SC, Rudolph DJ. Alterations of the trabecular pattern of the jaws in patients with osteoporosis. Oral Surg Oral Med Oral Pathol Oral Radiol Endod 1999; 88: 628-635.

14. Bollen AM, Taguchi A, Hujoel PP, Hollender LG. Fractal dimension on dental radiographs. Dentomaxillofac Radiol 2001; 30: 270-275.

15. Caligiuri $P$, Giger ML, Favus M. Multifractal radiographic analysis of osteoporosis. Med Phys 1994; 21: 503-508. 16. Tosoni GM, Lurie AG, Cowan AE, Burleson JA. Pixel intensity and fractal analyses: detecting osteoporosis in perimenopausal and postmenopausal women by using digital panoramic images. Oral Surg Oral Med Oral Pathol Oral Radiol Endod 2006; 102: 235-241.

17. Ingawale S, Goswami T. Temporomandibular joint: disorders, treatments, and biomechanics. Ann Biomed Eng 2009; 37: 976-996.

18. Muir CB, Goss AN. The radiologic morphology of asymptomatic temporomandibular joints. Oral Surg Oral Med Oral Pathol 1990; 70: 349-354. 
19. Hua Y, Nackaerts O, Duyck J, Maes F, Jacobs R. Bone quality assessment based on cone beam computed tomography imaging. Clin Oral Implants Res 2009; 20: 767 771.

20. White SC. Oral radiographic predictors of osteoporosis. Dentomaxillofac Radiol 2002; 31: 84-92.

21. Jett S, Shrout MK, Mailhot JM, Potter BJ, Borke JL. An evaluation of the origin of trabecular bone patterns using visual and digital image analysis. Oral Surg Oral Med Oral Pathol Oral Radiol Endod 2004; 98: 598-604.

22. Zeytinoglu $M$, Ihan $B$, Dundar N, Boyacioglu H. Fractal analysis for the assessment of trabecular peri-implant alveolar bone using panoramic radiographs. Clin Oral Investig 2015; 19: 519-524.

23. Ergun S, Saracoglu A, Guneri P, Ozpinar B. Application of fractal analysis in hyperparathyroidism. Dentomaxillofac Radiol 2009; 38: 281-288.

24. White SC, Cohen JM, Mourshed FA. Digital analysis of trabecular pattern in jaws of patients with sickle cell anemia. Dentomaxillofac Radiol 2000; 29: 119-124.

25. Pothuaud L, Lespessailles E, Harba R, Jennane R, Royant $\mathrm{V}$, et al. Fractal analysis of trabecular bone texture on radiographs: discriminant value in postmenopausal osteoporosis. Osteoporos Int 1998;8:618-625.

26. Ruttimann UE, Webber RL, Hazelrig JB. Fractal dimension from radiographs of peridental alveolar bone. A possible diagnostic indicator of osteoporosis. Oral Surg Oral Med Oral Pathol 1992; 74: 98-110.

27. Saeed SS, Ibraheem UM, Alnema MM. Quantitative Analysis by Pixel Intensity and Fractal Dimensions for Imaging Diagnosis of Periapical Lesions. Int J Enhanced Research in Science Technology \& Engineering 2014; 3: 138-144.

28. Yasar F, Akgunlu F. The differences in panoramic mandibular indices and fractal dimension between patients with and without spinal osteoporosis. Dentomaxillofac Radiol 2006; 35: 1-9.

29. Arsan B, Köse TE, Çene E, Özcan İ. Assessment of the trabecular structure of mandibular condyles in patients with temporomandibular disorders using fractal analysis. Oral Surg Oral Med Oral Pathol Oral Radiol 2017; 123: 382-391.

30. Demirbas AK, Ergun S, Guneri P, Aktener BO, Boyacioglu $\mathrm{H}$. Mandibular bone changes in sickle cell anemia: fractal analysis. Oral Surg Oral Med Oral Pathol Oral Radiol Endod 2008; 106: e41-e48.

31. Kayipmaz S, Akçay S, Sezgin ÖS, Çandirli C. Trabecular structural changes in the mandibular condyle caused by degenerative osteoarthritis: a comparative study by cone-beam computed tomography imaging. Oral Radiology 2019; 35: 51-58.

32. Akerman S, Kopp S, Rohlin M. Macroscopic and microscopic appearance of radiologic findings in temporo- mandibular joints from elderly individuals. An autopsy study. Int J Oral Maxillofac Surg 1988; 17: 58-63.

33. Flygare L, Rohlin M, Akerman S. Microscopy and tomography of erosive changes in the temporomandibular joint. An autopsy study. Acta Odontol Scand 1995; 53: 297-303.

34. Ahmad M, Schiffman EL. Temporomandibular Joint Disorders and Orofacial Pain. Dent Clin North Am 2016; 60:1 05-124.

35. Nah KS. Condylar bony changes in patients with temporomandibular disorders: a CBCT study. Imaging Sci Dent 2012; 42: 249-253.

36. Hussain AM, Packota G, Major PW, Flores-Mir C. Role of different imaging modalities in assessment of temporomandibular joint erosions and osteophytes: a systematic review. Dentomaxillofac Radiol 2008; 37: 63-71.

37. Devlin H, Karayianni K, Mitsea A, Jacobs R, Lindh C, et al. Diagnosing osteoporosis by using dental panoramic radiographs: the OSTEODENT project. Oral Surg Oral Med Oral Pathol Oral Radiol Endod 2007; 104: 821-828.

38. Kwong JC, Palomo JM, Landers MA, Figueroa A, Hans MG. Image quality produced by different cone-beam computed tomography settings. Am J Orthod Dentofacial Orthop 2008; 133: 317-327.

39. Ibrahim N, Parsa A, Hassan B, van der Stelt $P$, Aartman IHA, et al. Influence of object location in different FOVs on trabecular bone microstructure measurements of human mandible: a cone beam CT study. Dentomaxillofac Radiol 2014; 43: 20130329. 